Edukacja Dorostych 2021, $n$ r 2

ISSN 1230-929 X

http://dx.doi.org/10.12775/ED.2021.011

\title{
Monika Gromadzka
}

ORCID 0000-0001-6628-0357

\section{JÓZEF PÓŁTURZYCKI - NIEZWYKŁA POSTAĆ, WSPANIALY NAUCZYCIEL}

\begin{abstract}
Słowa kluczowe: Józef Półturzycki, aktywność naukowa, edukacja dorosłych, edukacja całożyciowa.

Streszczenie: Niniejszy artykuł jest krótkim opisem biografii naukowej jednego z najznakomitszych andragogów polskich, Prof. dra hab. Józefa Półturzyckiego. Okres jego życia zawodowego został podzielony na pięć etapów. Opis każdego z nich zawiera: przegląd podstawowych aktywności badawczych, ważne wydarzenia związane ze ścieżką zawodową, główne tematy podejmowane w publikacjach oraz działalność organizacyjną.
\end{abstract}

25 sierpnia 2021 zmarł wybitny polski andragog Prof. dr hab. Józef Półturzycki. Prawie całe swoje naukowe życie związany był z Uniwersytetem Warszawskim, gdzie najpierw pracował w Instytucie Pedagogicznego Kształcenia Nauczycieli, a następnie w Katedrze Edukacji Ustawicznej i Andragogiki, w której przez wiele lat był kierownikiem.

Wkład Profesora Półturzyckiego w rozwój polskiej pedagogiki, dydaktyki i andragogiki jest nieoceniony. Był autorem kilkudziesięciu książek i ponad setki artykułów naukowych, raportów oraz analiz. Był też członkiem Polskiej Akademii Nauk, gdzie przewodniczył Zespołowi Pedagogiki Dorosłych PAN. Profesor Półturzycki dziesięciokrotnie otrzymywał nagrodę Rektora Uniwersytetu Warszawskiego, ale był też uhonorowany Krzyżem Kawalerskim Orderu Odrodzenia Polski, Złotym Krzyżem Zasługi, Medalem 30-lecia Polski Ludowej, Medalem 40-lecia Polski Ludowej i Medalem Komisji Edukacji Narodowej. Przepracował tysiące godzin dydaktycznych, był też nauczycielem wielu pokoleń pedagogów i andragogów polskich. Wypromował 35 doktorów, ponad tysiąc magistrów, wielokrotnie był też członkiem komisji doktorskich czy habilitacyjnych. Bardzo ważnym aspektem jego pracy zawodowej było rozwijanie i umacnianie społeczności pedagogicznej i andragogicznej. Był jednym ze współzałożycieli oraz pierwszym 
i następnie wielokrotnie wybieranym Prezesem Akademickiego Towarzystwa Andragogicznego oraz aktywnie uczestniczył w pracach Polskiego Towarzystwa Pedagogicznego, Polskiego Towarzystwa Pedagogiki Porównawczej, Towarzystwa Uniwersytetów Ludowych, a także Stowarzyszenia Gerontologów Społecznych, gdzie był też członkiem komitetu założycielskiego. Z jego inicjatywy powołano kilka czasopism andragogicznych i dydaktycznych (,Rocznik Andragogiczny”, „Edukacja Dorosłych”, „Studia Dydaktyczne”), a wiele innych wspomagał swoją wiedzą i doświadczeniem zasiadając w ich radach redakcyjnych.

To krótkie wprowadzenie stanowi tylko faktograficzny skrót wielowątkowej kariery Profesora. Józef Półturzycki bowiem realizował się w działalności dydaktycznej i organizacyjnej oraz zawsze szczególną rolę przypisywał pracy badawczej. Nie sposób więc opisać na kilku stronach wszystkich jego działań, które prowadził przez ponad pięćdziesiąt pięć lat. Zaznaczam więc, że w niniejszym artykule przedstawię pewien tylko wycinek jego działalności, którą prowadził na wielu polach.

\section{Początki ${ }^{1}$}

Józef Półturzycki urodził się w Warszawie, a jego rodzicami byli inżynier geodeta oraz nauczycielka języka polskiego, była dyrektorka warszawskiej szkoły. Niedługo po urodzeniu się Józefa rodzina przeniosła się na tereny dzisiejszej Białorusi w okolice Nieświeża. Profesor często wspominał swoje wczesne dzieciństwo, które do wybuchu drugiej wojny światowej jawiło się w jego opowieściach sielankowo. Czas wojny był zaś okresem niepokoju, obawy, a potem ucieczki i tułaczki po Kresach, następnie zaś po Polsce. Rodzina osiadła wreszcie w Poznaniu, gdzie Profesor ukończył szkołę podstawową i Liceum im. Karola Marcinkowskiego. Po maturze, mając niecałe 17 lat, rozpoczął studia polonistyczne w Wyższej Szkole Pedagogicznej, a następnie na Uniwersytecie Warszawskim, na Wydziale Polonistyki. Tam też spotkał miłość swojego życia, Marię Różańską, która wkrótce potem została jego żoną. Spędzili ze sobą ponad sześćdziesiąt lat, a oprócz życia rodzinnego dzielili też pasje i zainteresowania, czego pokłosiem było m.in. kilka książek o tematyce biograficznej.

Od 1954 roku Profesor pracował w kilku warszawskich szkołach średnich. Właśnie to doświadczenie, szczególnie w pracy w liceach dla dorosłych, stało się inspiracją do pierwszych eksploracji badawczych. Józef Półturzycki pierwsze badania podjął po tym, jak dostał się na seminarium doktorskie do Prof. dr. hab. Wincentego Okonia. Badania te dotyczyły problematyki pracy domowej uczniów szkół dla dorosłych, a ich wyniki ogłoszone zostały w roku 1964 na łamach „Studiów

Zainteresowanych wczesnymi latami życia profesora odsyłałam do świetnego wywiadu, który przeprowadziła z Profesorem dr Renata Góralska (2015). Opublikowany został pod tytułem „Nauczyciele potrafią rozmiłować w swoim przedmiocie..." - pedagogiczne refleksje we wspomnieniach Mistrza w „Roczniku Andragogicznym” 2014. 
Pedagogicznych" (Półturzycki, 1964). Wspomniane badania były też podstawą jego dysertacji doktorskiej, którą obronił w 1966 roku. Do tegoż roku często wracał w swoich opowieściach, zarówno tych osobistych, jak i zawodowych. Wspominał, jak częstokroć, jeszcze przed obroną udawał się ze swoim promotorem i kolegami z seminarium do kawiarni hotelu Bristol, gdzie już w bardziej nieformalnej atmosferze godzinami dyskutowali lub słuchali opowieści Profesora Okonia. Józef Półturzycki, po latach prowadząc swoje seminaria, też starał się stworzyć przestrzeń do rozmów nie tylko tych merytorycznych, ale też codziennych. Sam również opowiadał anegdotki ze swojego życia, a szczególnie lubiliśmy te dotyczące jego obrony. Wielokrotnie były to zabawne historyjki, z których wyłaniał się jednak obraz trudnych powojennych czasów. Tak było między innymi z historią dotyczącą poczęstunku po obronie. Ponieważ okolice Uniwersytetu Warszawskiego jeszcze nie były w pełni odbudowane, to niestety nie było tam zbyt wielu kawiarni, a najbliższą była właśnie ta w hotelu Bristol. Zasadą było więc, że właśnie tam odbywały się tego typu spotkania. Niestety, kawiarnia ta była też niezwykle droga, szczególnie na kieszeń początkującego naukowca i nauczyciela. Profesor jednak bardzo chciał zaprosić swoich przyjaciół z pracy i bliskich, dlatego wraz z żoną miesiącami zbierali drobne monety do wielkiego słoja. Kwota została uzbierana, a mina człowieka, któremu Profesor płacił - jak twierdził - była bezcenna.

Badania wykorzystane podczas pracy nad dysertacją były też podstawą wydania nakładem PZWS książki O technice uczenia się dorostych (1966). Po tych pierwszych publikacjach badawczych pojawiały się liczne artykuły o organizacji i metodach pracy uczniów szkół wieczorowych i korespondencyjnych. Można powiedzieć, że właśnie w tym okresie narodziła się, trwająca całe życie zawodowe, fascynacja dydaktyką, a w szczególności dydaktyką dorosłych.

\section{Lata 1967-1981}

Od roku 1967 rozpoczyna się dla Profesora nowy rozdział. Praca doktorska została obroniona, materiały wydane, teraz był czas na nowe eksploracje i poszukiwanie swoich tematów.

Obrona doktoratu umożliwiła Profesorowi pracę naukową i organizacyjną w wielu liczących się w tamtym okresie placówkach (m.in. w Zakładzie Pedagogiki w Instytucie Polityki Naukowej i Szkolnictwa Wyższego). Jednak najważniejszym miejscem jego pracy, z którym bardzo mocno się utożsamiał, był Uniwersytet Warszawski. Jeszcze, gdy studiował na Wydziale Polonistyki, pojawily się pierwsze marzenia o dalszej pracy naukowej. Kiedy tylko nadarzyła się okazja, ażeby związać swoje dalsze losy zawodowe z Wydziałem Pedagogicznym UW, Profesor w ogóle się nie wahał. Przez cały dalszy okres swojego życia zawodowego (czyli do 2019 roku) jednostka ta stanowiła jego główne miejsce zatrudnienia. To w niej dalej rozwijał się i wspinał po drabinie naukowej poczynając od roku 1973, kiedy to na podstawie rozprawy Rozwój i problemy szkolnictwa dla 
dorostych w Polsce Ludowej (1972b) uzyskał stopień doktora habilitowanego. Od tego też momentu Profesor Półturzycki rozpoczął współpracę z doktorantami, którzy specjalizowali się w tematyce andragogicznej i dydaktycznej. Od roku 1976, kiedy to obronił się pierwszy z nich, dr Stefan Pacek, przez czterdzieści pięć lat Profesor służył swoją wiedzą i doświadczeniem kolejnym pokoleniom doktorantów. Jego ostatnim - trzydziestym piątym - doktorem był dr Jakub Sokolnicki, którego obrona odbyła się dosłownie kilka miesięcy przed śmiercią Profesora.

W tym okresie zaczęły się pojawiać bądź klarować tematy badawcze, które będą towarzyszyły Profesorowi przez całe jego dalsze życie zawodowe. Najpierw, jeszcze w 1967 roku ukazała się publikacja Ucz się sam - o technice samoksztatcenia (1967b), której celem było wsparcie dorosłych w samodzielnym uczeniu się: doborze metod, sposobach organizowania procesu itp. Także w 1967 roku Józef Półturzycki przygotował dla Ministerstwa Oświaty i Wychowania koncepcję badań dotyczących wyników nauczania języka polskiego w szkołach dla pracujących. $\mathrm{W}$ projekcie tym, oprócz roli organizatora, podjął się też opracowania wyników badań dotyczących nauczania literatury w klasach jedenastych. Badania przeprowadzono w 184 oddziałach, obejmując 5252 dorosłych uczniów. Ogłoszono je w rozprawie pod redakcją Haliny Gajewskiej: Rezultaty badań wyników nauczania języka polskiego w średnich szkołach dla pracujących (Półturzycki 1967a). Coraz częściej Profesor podejmował w swoich teoretycznych rozważaniach wątki dotyczące edukacji ustawicznej. Były to jeden z tych tematów, które Profesor zgłębiał jeszcze przez wiele lat swojej kariery zawodowej, a dziełem zwieńczającym całość będzie Spór o kształcenie ustawiczne opublikowany w 2016 roku.

Następnym tematem, który przez wiele lat będzie ogrywał ogromną rolę w życiu zawodowym Profesora, był ten dotyczący muzeów i publikacji biograficznych w edukacji dorosłych. Wraz z małżonką, nauczycielką języka polskiego, wydali książkę Muzea literackie w nauczaniu j. polskiego (Półturzycka, Półturzycki 1978), która była początkiem wielotomowego cyklu publikacji biograficznych.

W tym czasie Profesor zafascynował się również innym tematem, który zgłębiał właściwie do ostatnich lat aktywności zawodowej. Międzynarodowe badania porównawcze, bo o nich mowa, zapoczątkowane zostały podczas prac nad publikacjami: Kształcenie pracujacych w Zwiazku Radzieckim (1972a), Rozwój oświaty dorostych w państwach socjalistycznych (1981a) oraz Wspótczesne koncepcje oświaty dorostych $i$ ich realizacja $w$ wybranych krajach socjalistycznych $i$ kapitalistycznych (1981b). Tego rodzaju badania Profesor Półturzycki szczególnie chętnie będzie uprawiał na późniejszych etapach swojej kariery zawodowej.

\section{Lata 1982-1997}

Te piętnaście lat życia można uznać za początek chyba najintensywniejszej aktywności zawodowej Profesora. Nie tylko rozpoczął jeden z najważniejszych jak sam go określał - wieloetapowy międzynarodowy projekt badawczy, ale też 
prowadził inne badania naukowe oraz zaczął współpracę z nowymi instytucjami edukacyjnymi.

W roku 1984 w czasie wprowadzania nowych programów w szkołach podstawowych, a następnie średnich i zasadniczych zawodowych badano wyniki nauczania według dawnych i nowych programów, obowiązujących po wprowadzeniu zmian. W badaniach od 1985 do 1989 roku brało udział 8011 uczniów z 215 szkół, a także 2657 nauczycieli. Badano efekty nauczania ze wszystkich przedmiotów oraz postawy uczniów, zainteresowania, przygotowanie do samokształcenia, wykorzystywanie czasu wolnego i dalsze plany edukacyjne absolwentów. Badane szkoły wylosowano w 10 dawnych województwach i w Warszawie, w każdym z trzech środowisk: duże miasto, małe miasto, wieś. Badanie wykonane zostało w Instytucie Programów Szkolnych, a kierownikiem nadzorującym projekt i autorem koncepcji narzędzi był właśnie Profesor Józef Półturzycki. Wyniki badań przedstawiono w dziesięciu tomach: dotyczące szkół podstawowych w sześciu tomach, zasadniczych zawodowych - w dwóch i średnich - w dwóch. W 1994 J. Półturzycki opublikował także własną pracę podsumowującą ten projekt pt. Osiagnięcia absolwentów szkół polskich w latach 1985-1989 (Półturzycki, 1994).

Profesor wspominając swoje życie zawodowe, a w szczególności swoje projekty badawcze, ogromną rolę przypisywał tym prowadzonym we współpracy z pedagogami Uniwersytetu Humboldta w Berlinie (HUB): profesorami D. Schaale, Wiltrud Gieseke, i doktorami: H. Stock, J. Reichel, E. Schulze-Herman, Karin Opelt, Ingą Börjesson. Pierwszy etap tej współpracy rozpoczął się w roku 1990, kiedy to zespół specjalistów z Wydziału Pedagogicznego UW pod kierunkiem profesora Józefa Półturzyckiego zapoczątkował badania nad wyborem studiów i funkcjami wyższych uczelni. Ze strony Uniwersytetu Warszawskiego w badaniach brali udział pracownicy i doktoranci Uniwersytetu Warszawskiego, a ponadto profesor pozyskał do współpracy także osoby z innych uczelni, m.in.: prof. dr hab. Eugenię A. Wesołowską, prof. dr. hab. Józefa Kargula, dr hab. Hanna Solarczyk-Szwec, dr Renatę Góralską, dr Sylwię Słowińską i dr. Daniela Korzana.

Celem tego etapu badań było poznanie zmieniających się funkcji uczelni, a także przyczyn wyboru kierunku studiów przez studentów. W 1991 roku zbadano 248 osób z UW i 461 z HUB, natomiast w roku 1992 grupa badawcza wzrosła o 1649 studentów z UW i UMK w Toruniu oraz 1207 studentów z HUB i sześciu innych uczelni w Niemczech. Eksploracje przeprowadzono zgodnie z zaproponowanymi przez stronę niemiecką zasadami metodologicznymi, w których techniką badawczą była obszerna ankieta. Głównymi, przewidywanymi rezultatami badań były: ustalenie kierunków zmian w szkolnictwie wyższym, określenie problemów i rezultatów procesu transformacji, a także zbadanie motywów wyboru studiów i warunków studiowania w zmieniającej się sytuacji społecznej. Dodatkowo starano się wskazać różnice między uniwersytetami i studentami w Polsce i w Niemczech. Studenci mieli między innymi określić czynniki podnoszące efektywność studiowania, swój budżet czasu, aktywność poznawczą i samokształceniową, 
swoje postawy i formy aktywności politycznej. Całość uzyskanych rezultatów przedstawiona została w publikacji wydanej w dwóch wersjach językowych (polskiej i niemieckiej), której J. Półturzycki był współredaktorem (Depta, Półturzycki i Wesołowska, 1995a, 1995b).

W trakcie prowadzenia wspomnianych badań Profesor rozpoczął wieloletnią współpracę z Zakładem Dydaktyki w Instytucie Pedagogiki Uniwersytetu Mikołaja Kopernika w Toruniu, gdzie przez wiele lat, aż do 2002 roku, prowadził zajęcia oraz był promotorem i recenzentem licznych prac doktorskich. W tym okresie poznał też kilka osób, z którymi nie tylko współpracował, ale nawiązał też wieloletnie przyjaźnie.

Józef Półturzycki od początku wspierał przemiany w obszarze szkolnictwa wyższego. Uważał, że Polska powinna, podobnie jak kraje zachodnie, otworzyć się na możliwości związane ze szkolnictwem prywatnym. Wspierał ten proces nie tylko jako naukowiec, ale też praktyk, gdyż od lat dziewięćdziesiątych, przez około dwadzieścia kolejnych, był jednym z głównych organizatorów procesu nauczania i pierwszym dziekanem Wydziału Pedagogicznego w Wyższej Szkole im. Pawła Włodkowica w Płocku.

Ostatnia dekada XX wieku była też okresem, w którym Profesor Półturzycki koncentrował się na integrowaniu środowiska andragogów i dydaktyków. W 1993 roku powstało Akademickie Towarzystwo Andragogiczne, a jego prezesem został właśnie Profesor Józef Półturzycki. To właśnie z jego inicjatywy odbyły się pierwsze konferencje w Zakopanym czy Płocku. Większość z tych, zapoczątkowanych przez Profesora, cyklicznych spotkań odbywa się do dziś i można podczas ich trwania zapoznać się z badaniami prowadzonymi przez inne ośrodki, inspirować się ciekawymi referatami, czy wreszcie już w trochę bardziej nieformalnej atmosferze budować sieci badawcze i społeczne. Właśnie ten aspekt był dla Profesora Półturzyckiego niezmiernie ważny. W rozmowach wielokrotnie powtarzał, że efektywna konferencja powinna trwać dwa dni. Po godzinach wytężonej pracy naukowej uczestnicy wydarzenia powinni mieć możliwość spokojnej rozmowy, wymiany myśli i poznania się, bo według Profesora to właśnie mogło owocować ciekawymi projektami naukowymi.

W tym okresie Profesor wciąż rozwijał swoje zainteresowania związane z dydaktyką. Napisał książki, z których przez lata uczyć się będzie wiele pokoleń dydaktyków i andragogów, m.in.: Ksztatcenie Dorostych (1982), Lekcja w szkole wspótczesnej (1985), Dydaktyka dorostych (1991) czy Dydaktyka dla nauczycieli (1996). Ponownie też wraca do badań porównawczych, czego owocem są m.in. publikacje: Oświata dorostych w Szwecji (1984) czy Oświata dorostych w Japonii (1989b). Profesor kontynuował też rozważania dotyczące samokształcenia, najpierw publikując Wdrażanie do samokształcenia (1983), a następnie w Jak studiować zaocznie (1995). W tym czasie oprócz publikacji będących wynikiem wspomnianych wcześniej projektów pojawiają się też te, których źródłem były przemiany ustrojowe. Już w roku 1989 wydana została jego książka pod tytułem Kształtowanie się systemu 
oświaty dorostych w niepodległej Polsce (1989a). W 1992 roku zaś Profesor Pó1turzycki wraz z Panią Profesor Wesołowską redagują publikację pokonferencyjną, która była pokłosiem ogólnopolskiej konferencji „Tradycje i współczesne kierunki modernizacji dydaktyki”. Książka ukazuje się w 1993 roku pod tytułem Wspótczesne kierunki modernizacji dydaktyki (Półturzycki, Wesołowska, 1993). Można jednak zauważyć, że w tym okresie, prawdopodobnie z uwagi na liczne międzynarodowe i ogólnopolskie projekty naukowe, Profesor niejako zaniedbał tematykę biograficzną, do której jednak ponownie wróci za kilka lat.

\section{Lata 1998-2009}

Koniec XX i początek XX pierwszego wieku to w życiu Profesora czas równie aktywny jak poprzedni. Już sam 1998 był ważną cezurą, gdyż w tym właśnie roku Józef Półturzycki otrzymał tytuł profesora pedagogiki.

Po kilku latach Profesor wraca do przerwanego wątku i wraz z małżonką rozwija cykl biograficzny. Ukazują się publikacje: Muzea Adama Mickiewicza (2001), Ślady i pamiątki Jana Kochanowskiego (2003) i Ślady i pamiątki Prymasa Tysiąclecia. Sam pisze też dwie książki: Adam Mickiewicz jako nauczyciel i pedagog. Muzea Adama Mickiewicza (2005) oraz Aleksander Kamiński (2006). Razem z przyjaciółmi wydaje też książkę o bardzo ważnej dla niego osobie. Publikacja Kazimierz Sośnicki twórca dydaktyki polskiej (Góralska, Półturzycki, Wesołowska, Wojdyło, 2003) była w oczach Profesora Półturzyckiego niejako hołdem dla człowieka, który obok Profesora Wincentego Okonia był dla niego ogromną inspiracją i nauczycielem. Na wspomnienie zasługują też studia poświęcone Elżbiecie Zawackiej, których był też współredaktorem (Frąckowiak, Góralska, Półturzycki, Solarczyk-Szwec, Wojdyło, 2009a; Frąckowiak, Półturzycki, Solarczyk-Szwec, 2009b). W jednym z tomów znajdują się też pewne osobiste wątki i wspomnienia, gdyż Profesor miał zaszczyt współpracować z profesor Zawacką.

W tym okresie Profesor kontynuuje też wątek badań porównawczych i wydana zostaje Edukacja dorostych za granica (1998), która od razu staje się częścią kanonu lektur andragogicznych. Już na początku XXI wieku zaczyna współpracować z Profesorem jego ówczesna studentka, a następnie doktorantka, a obecnie doktor habilitowana, Anna Frąckowiak. To z nią przez następne lata Profesor będzie prowadził analizy porównawcze edukacji dorosłych w Kanadzie czy Stanach Zjednoczonych.

Schyłek XX wieku to też czas, w którym Profesor Półturzycki podjął się poprowadzenia drugiego etapu polsko-niemieckiej współpracy badawczej. Podczas tych badań również analizowano wybory studentów i funkcje uniwersytetu, ale też szczególny nacisk położono na określenie kultury studiowania w okresie transformacji. Grupę badawczą stanowiło 1206 osób, w tym z HUB - 366, z UMK - 404, a z UW - 436. W czasie tych badań porównano ogólną charakterystykę demograficzną studentów z trzech badanych uniwersytetów, określono motywy i metody 
indywidualnego uczenia się w czasie studiów. Określono typy i preferowane sposoby uczenia się, wskazano strategie studiowania, zakres współpracy z kolegami, aktywność w czasie wolnym i jej wpływ na wybrany kierunek studiów. Ważne stało się rozpoznanie obaw badanych studentów i spostrzeganych przez nich zagrożeń dla procesu studiowania, poznanie ich sytuacji ekonomicznej, uwikłań rodzinnych, podejmowanej pracy, form i zakresu rozrywek oraz innej aktywności kulturalno-oświatowej i sportowej. Ponad $80 \%$ badanych stwierdziło, że zna swój styl uczenia się i stara się go doskonalić. Zróżnicowane wyniki uzyskano odnośnie do posiadania i wykorzystywania komputerów: w Berlinie aż $85 \%$ badanych korzystało z tego rodzaju sprzętu, na UW - 52\%, a na UMK tylko $30 \%$. Materiał badawczy umożliwił nakreślenie kierunku przeobrażeń w formach aktywności i metodach studiowania oraz wskazanie istniejącej w tym zakresie potrzeby dalszych zmian. Wyniki badań (z komentarzem i kwestionariuszem ankiety) zostały opublikowane pod redakcją profesorów W. Gieseke i J. Półturzyckiego w 2001 roku (Kultura studiowania w okresie transformacji. Studium porównawcze) (Gieseke, Półturzycki, 2001). W tym samym roku ukazała się też, wydana przez HUB, niemiecka wersja tego raportu.

Przedmiotem zainteresowania w trzecim etapie współpracy badawczej polsko-niemieckiej stała się problematyka edukacji kulturalnej dorosłych. Do zespołu z HUB i UW dołączyli badacze z Uniwersytetu w Zielonej Górze, UMK, Wyższej Szkoły im. Pawła Włodkowica w Płocku. Przeprowadzono badania instytucji i placówek edukacji kulturalnej w Warszawie, województwie lubuskim, Toruniu i Płocku. Wyniki badań ukazały się w 2004 roku w tomie prac Edukacja kulturalna dorostych. Raporty z badań międzykulturowych (Depta, Półturzycki, Solarczyk, 2004). Owocem współpracy były też publikacje: Edukacja kulturalna dorosłych w Niemczech. Studium przypadku: Berlin - Brandenburgia (Depta, Półturzycki i Solarczyk-Szwec, 2005) i Kulturelle Erwachsenenbildung in Polen am Beispiel Lubuskie, Warschau und Ptock pod redakcją H. Depty, J. Kargula, J. Półturzyckiego (2005).

W tym okresie Profesor kontynuował też swoje wysiłki na rzecz integracji środowiska andragogicznego i wspierania młodych adeptów nauki. Wraz z Profesor Eugenią Wesołowską i Profesorem Józefem Kargulem powołują Letnią Szkołę Młodych Andragogów. Przez lata będzie to inicjatywa umożliwiająca osobom rozpoczynającym swoją karierę naukową udział $\mathrm{w}$ dyskusjach z wybitnymi naukowcami, wygłoszenie referatu czy otrzymanie rzetelnej informacji zwrotnej.

\section{Po 2010 roku}

Druga dekada dwudziestego wieku to czas stopniowego wycofywania się z pracy dydaktycznej i organizacyjnej. Niemniej jednak w ostatnim dziesięcioleciu swojego życia Profesor wydał (jako autor, współautor lub redaktor) jeszcze 9 książek i kilkanaście artykułów oraz wypromował 6 ostatnich doktorów. 
W tym też okresie trwał ostatni etap polsko-niemieckiej współpracy, w którym prace badawcze skoncentrowane były wokół problematyki instytucji edukacji kulturalnej, ze szczególnym uwzględnieniem muzeów biograficznych. Zespół badawczy z Polski pod kierownictwem Józefa Półturzyckiego badał muzea, wystawy i pamiątki związane z Fryderykiem Chopinem. Wyniki zostały przedstawione na konferencji w Ganshagen w lutym 2012 roku i ogłoszone w „Edukacji Otwartej” oraz tomie prac Muzea biograficzne w procesie edukacji kulturalnej. Ekspozycje Fryderyka Chopina (Depta, Gromadzka, Półturzycka, Półturzycki, 2013). Publikacja ta kończyła i podsumowywała wieloletnią współpracę badawczą między zespołem pedagogów z UW i HUB w zakresie edukacji dorosłych, edukacji kulturalnej i pedagogiki akademickiej. Na przestrzeni ponad dwudziestu lat wspólnych działań, obok opracowania wielu publikacji, organizowane były wymiany naukowe, narady robocze, a także konferencje w Berlinie, Warszawie, Zielonej Górze, Płocku, podczas których omawiano plany i założenia metodologiczne badań, analizowano uzyskane dane i ogłaszano ich rezultaty.

Ostatnie publikacje Józefa Półturzyckiego to eksploracje czterech głównych tematów, które przewijały się przez właściwie całe jego życie zawodowe. Pierwszym z nich były autorskie analizy zagranicznych systemów edukacji. Wraz z dr hab. Anną Frąckowiak zaprosił do współpracy wielu polskich andragogów i wspólnie opracowali dwa podręczniki: Edukacja ustawiczna w wybranych krajach Europy (Frąckowiak, Półturzycki, 2010) oraz Edukacja dorostych w wybranych krajach pozaeuropejskich (Frąckowiak, Półturzycki, 2011). Publikacje te były niejako zwieńczeniem jego analiz, które przez prawie 40 lat prowadził na tym polu naukowym. Sam temat edukacji w innych krajach - jak wielokrotnie powtarzał był dla niego niezmiernie ważny. Szczególną wagę przywiązywał do przybliżania polskiemu czytelnikowi wydarzeń, problemów i wyzwań o charakterze globalnym. Analizował więc światowe raporty, opisywał cykl Międzynarodowych Konferencji Edukacji Dorosłych, czy wreszcie pochylał się nad rozwiązaniami proponowanymi przez różne komisje i międzynarodowe gremia. Profesor uważał, że znajomość innych systemów i rozwiązań organizacyjnych w obszarze edukacji dorosłych powinna być wśród andragogów powszechna. Dzięki temu krytycznym okiem będą oceniali rodzime rozwiązania i proponowali te sprawdzone w innych krajach.

W ostatnich latach swojego życia wciąż interesował się też biografistyką i rolą muzeów biograficznych w edukacji dorosłych. W roku 2017 wraz z żoną i synem opublikował książkę traktującą o muzeach i ekspozycjach sławnych i zasłużonych Polek. Niestety, nie starczyło już czasu na realizację dalszych Jego planów, w których było opisanie kolejnych muzeów biograficznych polskich pisarzy, uczonych, mężów stanu i duchownych. Praca nad tą ostatnią publikacją pozwalała Józefowi Półturzyckiemu realizować jeszcze inną Jego pasję, którą były podróże. W ciągu swojego życia Profesor wraz z żoną zwiedził wiele zakątków Europy. W ostatnich jednak latach zdrowie już uniemożliwiało dalsze podróże, ale właśnie te projekty były pretekstem, aby wraz z synem lub ze mną Profesor mógł opracowywać trasy 
kolejnych wypraw po Polsce i osobiście zbierać materiały w wybranych muzeach biograficznych.

Zwieńczeniem Jego kariery była książka Samokształcenie w edukacji całożyciowej (Frąckowiak, Gromadzka, Półturzycki). Prace nad nią trwały kilka lat, projekt był odkładany z uwagi na inne bardziej bieżące tematy. Książka ta jednak musiała powstać i była niezwykle ważna dla Profesora. Wraz z publikacjami Niepokój o dydaktykę (2014b) oraz Spór o ksztatcenie ustawiczne. Polemiki i analizy (2016) miała ona być ostatnim „rozbudowanym” głosem w dyskusjach dotyczących obszarów badawczych, w których się specjalizował. Nie wykluczał, że napisze jeszcze kilka artykułów, ale to właśnie te książki miały być zwieńczeniem, zamknięciem pewnych rozdziałów.

Ostatnie dwa lata życia były dla Profesora Półturzyckiego niebywale trudne. W październiku 2019 roku zakończył wieloletnią współpracę z Uniwersytetem Warszawskim, a jego dalsze plany zawodowe związane z jedną ze szkół prywatnych pokrzyżowała pandemia. Już na samym jej początku, 1 kwietnia, zmarła też jego ukochana żona. Mimo wszystko Profesor nadal snuł plany związane z dalszymi publikacjami. Nawet $\mathrm{w}$ ostatnich miesiącach swojego życia wciąż był aktywny zawodowo: wypromował swojego ostatniego doktoranta, oddał do druku artykuł i zrecenzował publikację książkową. Wierzył, że za chwilę, już od września ponownie rozpocznie aktywną pracę nad następną publikacją naukową. Niestety...

Jak wspomniałam na początku tego artykułu, nie było możliwe opisanie wszystkich działań naukowych i badawczych, które Profesor prowadził przez pięćdziesiąt pięć lat swojego życia. W tym czasie powstało kilka publikacji opisujących jego twórczość. Do bardziej znaczących, do których odsyłam tych, chcących zdobyć więcej informacji o życiu i twórczości Profesora, należą: Profesor Józef Pótturzycki - w kręgu myśli i czynów (Skibińska i in., 2014), Autobiografia naukowa i zawodowa (Półturzycki, 2014a), „Nauczyciele potrafia rozmiłować w swoim przedmiocie..." - pedagogiczne refleksje we wspomnieniach Mistrza (Góralska, 2014) czy też artykuł autorstwa Henryka Bednarczyka, który ukazał się w czasopiśmie „Edukacja Ustawiczna Dorosłych” (2005).

O samych jego projektach badawczych, które prowadził w kooperacji z instytucjami zagranicznymi można by było napisać oddzielne studium. Profesor współpracował bowiem z wieloma uniwersytetami zagranicznymi, m.in.: Uniwersytetem Humboldta w Berlinie, w Lund, w Bielefeld, w Manchesterze, w Regensburgu, w Klagenfurcie, w Pradze, w Sankt Petersburgu czy w Bratysławie. Współpraca międzynarodowa nie ograniczała się jednak tylko do Uniwersytetów. Brał udział w pracach wielu znakomitych gremiów i organizacji m.in. Europejskiego Biura Edukacji Dorosłych, Instytutu Pedagogiki UNESCO w Hamburgu, Uniwersyteckiego Towarzystwa Edukacji Dorosłych czy Niemieckiego Towarzystwa Uniwersytetów Ludowych. Wszędzie, jeśli tylko miał możliwość, prowadził badania i popularyzował polską myśl pedagogiczną i andragogiczną. 
O jego rozległych zainteresowaniach i ogromnej pracowitości na polu naukowym świadczyć może imponująca wręcz bibliografia jego dorobku, której znaczącą część stanowią publikacje o charakterze badawczym. Był też niezwykłym nauczycielem i promotorem. Już w 2014 roku w swojej krótkiej autobiografii pisał, że wypromował 1648 magistrantów, a warto nadmienić, że potem jeszcze przez 5 lat prowadził seminaria magisterskie i przygotowywał do obrony studentów uniwersytetu i dwóch innych szkół wyższych. Wypromował ponad trzydziestu pięciu doktorów, a w wielu przewodach był recenzentem.

Nie tylko jednak powyższe liczby świadczą o tym, że Profesor był doskonałym mentorem. Był on bowiem nauczycielem, który chętnie wspierał swoich uczniów w ich aktywnościach naukowych. Zapraszał do swoich publikacji nawet magistrów, inicjował projekty czy wreszcie budował zespoły, w których zawsze było miejsce dla początkujących naukowców. Najlepszym świadectwem są Jego wychowankowie, którzy do końca Jego życia utrzymywali z Profesorem kontakt, i którzy częstokroć wciąż poszukiwali u swego mentora naukowych rad i cennych wskazówek.

Na koniec chcę dodać, że dla wielu z nas - uczniów i współpracowników - był też dobrym kolegą, przyjacielem... Człowiekiem, który służył pomocą i wsparciem w wielu sytuacjach życiowych. Spotkania z Profesorem nigdy nie były nudne, bo znał niesamowitą wręcz liczbę anegdotek i miał też niebywałe poczucie humoru. Godzinami w arcyciekawy sposób potrafił opowiadać historie o wielu znakomitych Polkach i Polakach. A ponieważ był pasjonatem literatury i historii, to też i jego opowieści obfitowały w wiele mniej znanych faktów. Dyskusje z Profesorem to była prawdziwa intelektualna przygoda i wielu z nas będzie je długo wspominać. Józef Półturzycki potrafił też po prostu „być” w relacji: interesował się naszym życiem, znał imiona bliskich, a co najistotniejsze dawał nam to, co chyba najważniejsze w kontaktach z ludźmi: czas i uwagę. Będziesz zawsze żył w naszej pamięci Józefie!

Profesor dr hab. Józef Półturzycki spoczął na Powązkach Wojskowych w Warszawie, gdzie dnia 9 września 2021 roku podczas uroczystości pogrzebowych pożegnała go rodzina, przyjaciele i liczni znajomi, współpracownicy i uczniowie.

\section{Bibiliografia}

Bednarczyk, H. (2005). Józef Półturzycki, Edukacja Ustawiczna Dorostych”, nr 1, s. 79-81.

Depta, H., Gromadzka, M., Półturzycka, M., Pólturzycki, J. (2013). Muzea biograficzne w procesie edukacji kulturalnej. Ekspozycje Fryderyka Chopina. Radom: Wydawnictwo Naukowe Instytutu Technologii Eksploatacji - PIB.

Depta, H., Kargul, J., Półturzycki, J. (2005). Kulturelle Erwachsenenbildung in Polen am Beispiel Lubuskie, Warschau und Płock, Wyd. Warman, Münster. 
Depta, H., Półturzycki, J., Solarczyk H. (2004). (red.). Edukacja kulturalna dorostych: raporty z badań międzykulturowych. Warszawa - Płock - Radom: Wydawnictwo Naukowe Instytutu Technologii Eksploatacji - PIB.

Depta, H., Półturzycki, J., Solarczyk-Szwec, H. (2005). (red. wyd. polskiego). Edukacja kulturalna dorostych w Niemczech: studium przypadku: Berlin/Brandenburgia. Warszawa - Płock: Wydział Pedagogiczny Uniwersytetu Warszawskiego i Szkoła Wyższa im. Pawła Włodkowica w Płocku.

Depta, H., Półturzycki, J., Wesołowska, E.A. (red.). (1995a). Studenci a uniwersytet. Badania nad wyborem studiów i funkcjami uczelni. Torun: Wydawnictwo A. Marszałek.

Depta, H., Półturzycki, J., Wesołowska, E.A. (red.). (1995b). Studenten an Universitäten: Untersuchungenüber die Erwaltungshaltungen der Studenten und die Rolle der Universitäten. Toruń: Wydawnictwo A. Marszałek.

Frąckowiak, A., Góralska, R., Półturzycki, J., Solarczyk-Szwec, H., Wojdyło, W. (red.). (2009), Elżbieta Zawacka 1909-2009. Radom: Instytut Technologii Eksploatacji PIB.

Frąckowiak, A., Gromadzka, M., Półturzycki, J. (2019). Samokształcenie w edukacji całozyciowej. Radom - Warszawa: Sieć Badawcza Łukasiewicza - Instytut Technologii Eksploatacji, Wydawnictwo Naukowe.

Frąckowiak, A., Półturzycki, J. (red.). (2010). Edukacja dorosłych w wybrananych krajach Europy, Warszawa: Wydawnictwo Żak.

Frąckowiak, A., Półturzycki, J. (red.). (2011). Edukacja dorosłych w wybrananych krajach pozaeuropejskich, Warszawa: Wydawnictwo Żak.

Frąckowiak, A., Półturzycki, J., Solarczyk-Szwec, H. (red.). (2009). Elżbieta Zawacka. Pisma pedagogiczne. Radom: Instytut Technologii Eksploatacji - PIB.

Gieseke, W., Półturzycki, J. (red.), (2001). Kultura studiowania w okresie transformacji. Studium porównawcze, Warszawa: Wydawnictwo „Żak”.

Góralska, R. (2014). „Nauczyciele potrafią rozmiłować w swoim przedmiocie...” - pedagogiczne refleksje we wspomnieniach Mistrza, Rocznik Andragogiczny, 21, s. 33-48.

Góralska, R., Półturzycki, J., Wesołowska E.A., Wojdyło, W. (red.). (2003). Kazimierz Sośnicki twórca dydaktyki polskiej. Toruń - Płock: Wydawnictwo Naukowe NOVUM.

Półturzycka, M., Półturzycki, J. (1978). Muzea literackie w nauczaniu języka polskiego. Warszawa: WSiP.

Półturzycka, M., Półturzycki, J. (2001). Muzea Adama Mickiewicza, Wydawnictwo Naukowe NOVUM Płock.

Półturzycka, M., Półturzycki, J. (2003). Ślady i pamiątki Jana Kochanowskiego. Radom: ITeE - PIB.

Półturzycka, M., Półturzycki, J., Półturzycki, M. (2017). Muzea kobiet polskich. Radom: Wydawnictwo Naukowe Instytutu Technologii i Eksploatacji - PIB.

Półturzycki, J. (1964). Praca domowa uczniów szkół dla dorosłych. Studia Pedagogiczne tom XI, s. 255-274.

Półturzycki, J. (1966). O technice uczenia się dorosłych. Warszawa: Państwowy Zakład Wydawnictw Szkolnych.

Półturzycki, J. (1967a). Analiza wyników znajomości literatury w klasach jedenastych. W: Gajewska H. (red.). Rezultaty badań wyników nauczania języka polskiego w średnich szkołach dla pracujacych. Warszawa: Wyd. MOISIW-COM, s. 72-88.

Półturzycki, J. (1967b). Ucz się sam - o technice samokształcenia. Warszawa: Instytut Wydawniczy CRZZ. 
Półturzycki, J. (1972a). Kształcenie pracujących w Związu Radzieckim. Warszawa: PWN. Półturzycki, J. (1972b). Rozwój i problemy szkolnictwa dla dorostych w Polsce Ludowej. Wrocław: Wydawnictwo Zakład Narodowy im. Ossolińskich.

Półturzycki, J. (1981a). Rozwój oświaty dorostych w państwach socjalistycznych. Warszawa: WSiP.

Półturzycki, J. (1981b). Współczesne koncepcje oświaty dorostych i ich realizacja w wybranych krajach socjalistycznych i kapitalistycznych. Warszawa: Instytut Badań Pedagogicznych.

Półturzycki, J. (1982). Kształcenie dorostych. Warszawa: Instytut Badań Pedagogicznych.

Półturzycki, J. (1983). Wdrażanie do samokształcenia. Warszawa: WSiP.

Półturzycki, J. (1984). Oświata dorostych w Szwecji. Warszawa: ZG TWP.

Półturzycki, J. (1985). Lekcja w szkole wspótczesnej. Warszawa: WSiP.

Półturzycki, J. (1989a). Kształtowanie się systemu oświaty dorostych w niepodległej Polsce, Warszawa.

Półturzycki, J. (1989b). Oświata dorostych w Japonii. Warszawa: Zarząd Główny TWP.

Półturzycki, J. (1991). Dydaktyka dorostych. Warszawa: WSiP.

Półturzycki, J. (1994). Osiagnięcia absolwentów szkół polskich w latach 1985-1989. Toruń: Wyd. UMK.

Półturzycki, J. (1995). Jak studiować zaocznie. Toruń: Wydawnictwo Adam Marszałek.

Półturzycki, J. (1996). Dydaktyka dla nauczycieli. Toruń: Wydawnictwo Adam Marszałek.

Półturzycki, J. (1998). Edukacja dorostych za granica. Toruń: Wydawnictwo Adam Marszałek.

Półturzycki, J. (2005). Adam Mickiewicz jako nauczyciel i pedagog. Muzea Adama Mickiewicza. Płock: Wydawnictwo Naukowe NOVUM.

Półturzycki, J. (2006). Aleksander Kamiński. Radom: Instytut Technologii Eksploatacji - PIB.

Półturzycki, J. (2014a). Autobiografia naukowa i zawodowa. Studia Dydaktyczne, 26, s. $13-19$.

Półturzycki, J. (2014b). Niepokój o dydaktykę. Warszawa - Radom: Instytut Technologii Eksploatacji - PIB.

Półturzycki, J. (2016). Spór o kształcenie ustawiczne. Polemiki i analizy. Warszawa - Radom: Wydawnictwo ITeE - PIB.

Półturzycki, J., Wesołowska, E.A. (red.). (1993). Współczesne kierunki modernizacji dydaktyki. Materiały z ogólnopolskiej konferencji w dniach 20-21 stycznia 1992. Toruń: Wydawnictwo Uniwersytetu Mikołaja Kopernika.

Skibińska, E., Pierścieniak, K., Dębska, E., Pleskot-Makulska, K., Marianowska, A., Gromadzka, M. (2014). Profesor Józef Półturzycki - w kręgu myśli i czynów. Studia Dydaktyczne, 26, s. 31-59. 


\section{JÓZEF PÓŁTURZYCKI AN EXTRAORDINARY FIGURE AND WONDERFUL TEACHER}

Keywords: Józef Półturzycki, scientific activity, adult education, lifelong learning.

Summary: Summary: the article is a short description of the scientific biography of one of the most outstanding Polish specialists of Adult Education, prof. dr hab. Józef Półturzycki. His professional biography is divided into five intervals. The description of each includes an overview of the scientific activities, significant events related to the career path, main topics undertaken in publications, and organizational activity.

Dane do korespondencji:

Dr Monika Gromadzka

Zakład Edukacji Ustawicznej i Adnragogiki

Wydział Pedagogiczny

Uniwersytet Warszawski

ul. Mokotowska 16/20

00-561 Warszawa

e-mail: monika.gromadzka@uw.edu.pl 